\title{
High numbers of activated helper T cells are associated with better clinical outcome in early stage vulvar cancer, irrespective of HPV or p53 status
}

Kim E. Kortekaas ${ }^{1,3}$, Saskia J. Santegoets ${ }^{3}$, Ziena Abdulrahman³, Vanessa J. van Ham³ ${ }^{3}$ Marij van der Tol ${ }^{2}$, Ilina Ehsan ${ }^{3}$, Helena C. van Doorn ${ }^{4}$, Tjalling Bosse ${ }^{5}$, Mariëtte I. E. van Poelgeest ${ }^{2+}$ and Sjoerd H. van der Burg ${ }^{3 *+}$ (D)

\begin{abstract}
Background: Vulvar squamous cell carcinoma (VSCC) has been suggested to consist of three subtypes; HPVpositive, HPV-negative mutated TP53 or HPV-negative TP53 wildtype, with different clinical courses. To analyze the immune infiltrate in these molecular subtypes and its impact on clinical outcome, an in-depth study of the tumor immune microenvironment was performed.
\end{abstract}

Methods: Sixty-five patients with invasive VSCC matched for age, FIGO stage and treatment modality, were grouped according to the presence of HPV and p53 protein expression status. Archived tissues were analyzed for intraepithelial and stromal expression of CD3, CD8, Foxp3, PD-1, and pan-keratin in randomly selected areas using immunofluorescence. Additional phenotyping of T cells was performed ex-vivo on VSCC $(n=14)$ and blood samples by flow cytometry. Healthy vulvar samples and blood served as controls.

Results: Based on T-cell infiltration patterns about half of the VSCC were classified as inflamed or altered-excluded while one-third was immune-deserted. High intraepithelial helper T cell infiltration was observed in 78\% of the HPVinduced VSCC, 60\% of the HPVnegVSCC/p53wildtype and 40\% of the HPVnegVSCC with abnormal p53 expression. A high intraepithelial infiltration with activated $\left(\mathrm{CD}^{+} \mathrm{PD}-1^{+}\right)$, specifically helper $\mathrm{T}$ cells $\left(\mathrm{CD}^{+}{ }^{+} \mathrm{CD} 8^{-}\right.$Foxp3 $\left.{ }^{-}\right)$, was associated with a longer recurrence-free period and overall survival, irrespective of HPV and p53 status. Flow cytometry confirmed the tumor-specific presence of activated $\left(\mathrm{CD} 4^{+} \mathrm{PD}-1^{++} \mathrm{CD} 161^{-} \mathrm{CD} 38^{+} \mathrm{HLA}-\mathrm{DR}{ }^{+}\right.$and $\mathrm{CD}^{+} \mathrm{CD}_{103}{ }^{+} \mathrm{CD} 161^{-} \mathrm{NKG} 2 \mathrm{~A}^{+/-}{ }^{-P D} 1^{++} \mathrm{CD} 38^{++} \mathrm{HLA}-\mathrm{DR}{ }^{+}$) effector memory $\mathrm{T}$ cells.

Conclusion: This is the first study demonstrating an association between intraepithelial T cells and clinical outcome in VSCC. Our data suggest that abnormal p53 expressing VSCCs mostly are cold tumors whereas HPV-driven VSCCs are strongly T-cell infiltrated.

Keywords: Vulvar cancer, Tumor microenvironment, Immunotherapy, T cells, PD-1

\footnotetext{
* Correspondence: shvdburg@lumc.nl

${ }^{\dagger}$ Mariëtte I. E. van Poelgeest and Sjoerd H. van der Burg contributed equally

to this work.

${ }^{3}$ Department of Medical Oncology, Oncode Institute, Leiden University

Medical Centre, PO Box 9600, 2300 RC Leiden, The Netherlands

Full list of author information is available at the end of the article
}

(c) The Author(s). 2019 Open Access This article is distributed under the terms of the Creative Commons Attribution 4.0 International License (http://creativecommons.org/licenses/by/4.0/), which permits unrestricted use, distribution, and reproduction in any medium, provided you give appropriate credit to the original author(s) and the source, provide a link to the Creative Commons license, and indicate if changes were made. The Creative Commons Public Domain Dedication waiver (http://creativecommons.org/publicdomain/zero/1.0/) applies to the data made available in this article, unless otherwise stated. 


\section{Introduction}

Immunotherapy of cancer has established itself as a new breakthrough approach that offers long-term durable clinical responses in patients with advanced cancers. As the initiation and regulation of the immune response to tumors is complex and multistep in nature, inspection of the different processes involved is required to provide the optimal (combination) of immunotherapeutic modalities available [1]. This is highly relevant for vulvar squamous cell carcinoma (VSCC), the predominant histologic subtype of vulvar cancers, for which new treatment options are urgently needed. Because despite current treatment, consisting of radical surgery and/or (chemo) radiotherapy which causes impressive morbidity, lymphedema, sexual and psychological dysfunction and wound healing disorders [2, 3], 46\% of VSCC patients still develop recurrences after 10-years [4].

At this point however, little is known about the role and impact of cellular immunity on the clinical outcome of VSCC. Both CD4 and CD8 T cells as well as B cells infiltrate VSCC [5-7]. The CD4 cells comprise $\mathrm{CD}^{+}$helper $\mathrm{T}$ cells and regulatory $\mathrm{T}$ cells (Tregs). Often a strong infiltration with one type of $\mathrm{T}$ cells is paralleled by the others $[5$, $6,8]$. In three studies focussing on the prognostic role of $\mathrm{CD}^{+}$and/or $\mathrm{CD}^{+} \mathrm{T}$ cells or Tregs no impact on clinical outcome was found $[6,9,10]$. On the one hand, these analyses may have been influenced by the heterogeneity of the study group with respect to tumor etiology, stage and treatment. Furthermore, enumeration of all $\mathrm{T}$ cells, irrespective of their location in the tumor [9], as well as preselection of highly infiltrated areas only $[6,10]$, may also have influenced study outcomes. On the other hand, the impact of $\mathrm{T}$ cells may be nullified by the presence of immune regulatory mechanisms, as VSCC can be massively infiltrated with M2 macrophages and Tregs [8]. Moreover, VSCC can express the immunoregulatory enzyme, indoleamine 2,3-dioxygenase (IDO) or PD-L1, both of which were shown to negatively influence clinical outcome [10, 11]. Notably, PD-L1 was mainly expressed in lymphocyte rich areas [11], suggesting that it functioned as an adaptive escape mechanism [12], and implying that in some VSCC a functionally active antitumor response is present. This notion is sustained by the observation that the intraepithelial presence of Granzyme B-positive cells is related to better overall survival (OS) in patients with localized VSCC [13].

At present, three distinct etiologic pathways in the development of VSCC have been proposed. One type is driven by the overexpression of high-risk human papilloma virus oncogenes E6 and E7 (HPVposVSCC). The second type is not related to HPV and can be categorized based on the mutational status of the tumor suppressor gene TP53 associated with high protein levels of p53 (HPVnegVSCC/ p53abn). We recently identified a third type as a substantial group of patients with a HPV-negative VSCC displaying normal expression levels of p53 protein (HPVnegVSCC/ p53wt) but frequently bearing other mutations [14]. Importantly, HPV-driven VSCC display better OS and a longer recurrence-free period (RFP) than HPVnegVSCC [14-17]. Interestingly among the latter group, local recurrences more often occurred after treatment in patients with HPVnegVSCC/p53abn than in HPVnegVSCC/p53wt [14]. With the first reports showing an influence of different oncogenic pathways on local immunity $[18,19]$, we asked the question if the differences in RFP and OS observed between the three groups of VSCC driven by different oncogenic pathways could be explained by the local immune response. Bearing in mind the limitations of previous studies, we selected three cohorts of VSCCs based on their HPV and p53 protein (abn/wt) status which were highly matched for clinicopathological parameters and enumerated different types of intraepithelial and stromal $\mathrm{T}$ cells in randomly selected fields of VSCC, using multiplex immunofluorescence. In-depth analysis of $\mathrm{T}$ cells was performed on freshly dispersed tissue by flow cytometry. Our study revealed a strong impact of intraepithelial activated $\mathrm{T}$ cells on clinical outcome, in particular a dense infiltration with intraepithelial $\mathrm{CD} 4^{+} \mathrm{T}$ cells was highly associated with RFP and OS, irrespective of HPV or p53 status. Moreover, the percentage of tumors highly infiltrated with these $\mathrm{T}$ cells varied between the three different subtypes, with HPV-induced VSCC most often strongly infiltrated (78\%) followed by the HPVnegVSCC/p53wt (60\%) and the lowest infiltration in the HPVnegVSCC/p53abn group (40\%).

\section{Material and methods}

Patient materials

Archived formalin-fixed paraffin-embedded (FFPE) tumor tissue from VSCC patients was selected from a larger cohort with known HPV and p53 status. HPV presence was tested by HPV-PCR and p16 IHC [20]. Tumors that were positive in both tests were assigned as HPVposVSCC. When both tests were negative, tumors were scored as HPVnegVSCC. The HPVnegVSCC were further sub-classified based on the wildtype or abnormal expression of p53 (HPVnegVSCC/p53wt and HPVnegVSCC/p53abn) as previously described [14]. In addition, archived FFPE healthy HPV-negative vulvar tissue from 10 women who underwent labial reduction surgery served as controls. Fresh tumor tissue $(n=14)$ and blood samples $(n=34)$ were obtained from 38 patients participating in the large observational CIRCLE study. Women with histologically proven p16 ${ }^{\text {ink4a }}$-negative VSCC were included in this study investigating cellular immunity against anogenital lesions [21, 22]. Tumor staging was done according to FIGO staging 2009. Patients were included after signing informed consent. The study was conducted in accordance with the Declaration of Helsinki and approved by the local medical ethical committee of the Leiden University Medical Center (P08.197 and 
B16.024) and in agreement with the Dutch law. The materials were used according to the Dutch Federation of Medical Research Association guidelines. The patients received standard-of-care treatment consisting of primary surgery.

\section{Multiplex six color staining, image acquisition and analysis by VECTRA}

For the direct and indirect immunofluorescent six color staining and detection, $4 \mu \mathrm{m}$ FFPE tissue sections were deparaffinized and prepared with heat-induced antigen citrate $(10 \mathrm{mM}, \mathrm{pH} 6.0)$ retrieval as described previously [23]. Antibody specificity and optimal conditions for antigen retrieval were assessed by single-plex IHC using tonsils as a positive control [23]. After incubation with superblock buffer (Thermo Fisher Scientific, Waltham, MA, USA), the primary antibodies and isotype/species-specific secondary fluorescent antibodies were applied (Additional file 1). Nuclear counterstain was obtained with DAPI. Tissue slides were imaged at $20 \mathrm{x}$ magnification with the Vectra 3.0 Automated Quantitative Pathology Imaging System (Perkin Elmer). Imaging analysis and spectral separation of dyes was performed with the InForm Cell Analysis software (Perkin Elmer) by using spectral libraries defined with single-marker immunofluorescence detection. Five random multispectral imaging fields of interest were selected for acquisition from each tumor, depending on its size. Tissue and cellular segmentation was done as described before [23]. The following phenotypes were identified for the $\mathrm{T}$ cell panel: total $\mathrm{T}$ cells $\left(\mathrm{CD}^{+}\right), \mathrm{CD}^{+} \mathrm{T}$ cells $\left(\mathrm{CD}^{+} \mathrm{CD}^{+}{ }^{+} \mathrm{Foxp}^{-}\right)$, helper $\mathrm{T}$ cells $\left(\mathrm{CD}^{+} \mathrm{CD}^{-} \mathrm{Foxp}^{-}\right)$, Tregs $\left(\mathrm{CD}^{+} \mathrm{CD}^{-} \mathrm{Foxp}^{+}\right)$, PD-1 expressing $\mathrm{T}$ cells $\left(\mathrm{CD}^{+}{ }^{+} \mathrm{PD} 1^{+}\right)$. All images were visually inspected to confirm the correct attribution and quantification of phenotypes, and segmentation of tissue. Because PD1 could be expressed by $\mathrm{CD}^{+} \mathrm{CD}^{-}$and $\mathrm{CD}^{+} \mathrm{CD}^{+}$cells, the $\mathrm{CD}^{+}{ }^{+} \mathrm{PD} 1^{+}$phenotypes were separately analyzed. All phenotypes in both areas were normalized by tissue area (number of cells $/ \mathrm{mm}^{2}$ ). In addition, ten HPVposVSCC, six HPVnegVSCC/p53wt and five HPVnegVSCC/p53abn VSCC samples were used to study Tbet (Santa Cruz, clone $\mathrm{H}-210$, dilution 1:100) expressing $\mathrm{CD}^{+}$cells with immunofluorescence.

\section{Blood and tumor cell isolation and culturing}

Venous blood samples were drawn prior to surgery, and peripheral blood mononuclear cells (PBMC) were isolated using Ficoll density gradient centrifugation as described previously [24, 25]. VSCC tumor material was obtained and handled as described [24, 25]. First, tumor material was cut into small pieces. One-third of the tumor pieces was incubated for $60 \mathrm{~min}$ at $37^{\circ} \mathrm{C}$ in Iscove's Modified Dulbecco's Medium (IMDM, Gibco by life technologies, ThermoFisher Scientific, Lonza, Verviers, Belgium) with $10 \%$ human AB serum (Capricorn Scientific, Esdorfergrund, Germany) and supplemented with high dose of antibiotics $(50 \mu \mathrm{g} / \mathrm{ml}$ Gentamycin (Gibco/ Thermo Fisher Scientific (TFS), Bleiswijk, the Netherlands), $25 \mu \mathrm{g} / \mathrm{ml}$ Fungizone (Gibco/Thermo Fisher Scientific), after which the tumor pieces were put in culture in IMDM supplemented with 10\% human AB serum (IMDM complete) and $1000 \mathrm{IU} / \mathrm{ml}$ human recombinant IL-2 (Aldesleukin, Novartis, Arnhem, the Netherlands). Cultures $(n=14)$ were replenished every 2-3 days with fresh IMDM complete and IL-2 to a final concentration of $1000 \mathrm{IU} / \mathrm{ml}$. After 2-4 weeks, when sufficient T cells were obtained, the cells were cryopreserved and stored in liquid nitrogen until use. Approximately two-third of the tumor pieces was incubated for $15 \mathrm{~min}$ at $37^{\circ} \mathrm{C}$ in IMDM dissociation mixture containing $10 \%$ human $\mathrm{AB}$ serum, high dose of antibiotics (as above) and $0.38 \mathrm{mg} / \mathrm{ml}$ of the commercially available Liberase enzymes (Liberase TL, research grade, Roche). Following incubation, cell suspension was put on a $70 \mu \mathrm{m}$ cell strainer (Falcon, Durham, NC, USA) to obtain a single cell suspension, counted using trypan blue exclusion (Sigma, St Louis, MO, USA), and cryopreserved at approximately 2 million cells/vial. All cells were stored in the vapor phase of liquid nitrogen until further use.

\section{Flow cytometry and data analysis}

Cryopreserved PBMC $(n=34)$ and/or cryopreserved freshly isolated single cell tumor samples $(n=12)$ were thawed and assessed by flow cytometry as described before [26, 27]. In brief, samples were thawed according to standard operation procedures and stained with the LIVE-DEAD $^{\circ}$ Fixable yellow dead cell stain kit (Thermo Fisher Scientific) for $20 \mathrm{~min}$ at room temperature to identify dead cells. Following incubation, the cells were washed, incubated with PBS/0.5\%BSA/10\%FCS for $10 \mathrm{~min}$ on ice to block Fc receptors. After the cells were washed, the cells were stained for $30 \mathrm{~min}$ on ice and in the dark with fluorochrome-conjugated antibodies. Intracytoplasmic/intranuclear staining was conducted with the $\mathrm{BD}$ Pharmingen Transcription Factor Buffer set (BD Biosciences) according to manufacturers' protocol. Details on antibodies used are listed in Additional file 1. Acquisition of cells was done on a BD LSR Fortessa. Data was analyzed by either manual gating using DIVA software (version 8.02; BD Biosciences) or by high-dimensional single cell data analysis using hierarchical Stochastical Neighbor Embedding (HSNE) [28] in Cytosplore. To automatically discover stratifying biological signatures at the single cell level, we used the fully automated hierarchical clustering (unsupervised) tool CITRUS in the cloud-based cytobank software (Fluidigm Sciences) with an FDR of $1 \%$. 


\section{Cytokine production of phytohemagglutinin (PHA)- stimulated TIL}

To determine capacity of tumor infiltrating lymphocyte (TIL) batches from HPVnegVSCC tumors to produce cytokines in response to mitogenic stimulation, cultured TIL batches $(n=14)$ were stimulated with $0.5 \mu \mathrm{g} / \mathrm{ml}$ PHA (HA16 Remel; ThermoFischer Scientific) for 4 days, after which supernatants were harvested and analyzed by Cytometric Bead Array (CBA, Th1/Th2 kit, BD Bioscience, Breda, the Netherlands) according to the manufacturer's instructions. The cut-off value for cytokine production was $20 \mathrm{pg} / \mathrm{ml}$, except for IFN- $\gamma$ for which it was $100 \mathrm{pg} / \mathrm{ml}$. Positive cytokine production was defined as at least twice above that of the unstimulated cells $[25,29]$.

\section{Statistical analysis}

For data analysis the statistical software package SPSS 23.0 (SPSS Inc., Chicago, IL) was used. Group comparisons of categorical data were performed by chi-square test. The non-parametric Mann-Whitney U test was used for continuous variables when comparing two groups. For the survival analysis, patients were categorized into two groups based on numerical immune cell count. First, the median cell count was used as cut-off value. To optimize the chance to detect a relationship between $\mathrm{T}$-cell subsets and clinical outcome in a relatively small group of patients, the best cut-off value for the different $\mathrm{T}$ cell subsets was determined using receiver operating characteristics (ROC) curve analysis. The T-cell subset values with the best accuracy (i.e. with greatest sensitivity and specificity) were selected as the most optimal cut-off value for (OS or RFP). Based on these cut-off values, the immune cell counts were categorized in two groups and a log-rank test was performed to calculate the difference in OS or RFP. The RFP was censored for lost-to-follow up and death. Two sided $p$-values $<0.05$ were considered significant. GraphPad Prism 7 (GraphPad Software Inc., LA Jolla, CA, USA) was used to illustrate the data by graphs and figures.

\section{Results}

\section{Patient cohort}

A cohort of 65 primary VSCC samples, divided in HPVposVSCC ( $n=23)$, HPVnegVSCC/p53wt $(n=20)$, and HPVnegVSCC/p53abn $(n=22)$ was analyzed. All cases were matched for age (40-85 years), FIGO stage, absence of lymph node and distant metastasis, $\geq 8 \mathrm{~mm}$ tumor-free margins, no use of immunosuppression, and no documented medical history. However, HPVposVSCC were younger than the other groups despite matching because younger women are more likely to have HPVposVSCC than HPVnegVSCC [30]. An overview of patient characteristics and treatment is given in Additional file 2. In line with current literature [15, 17, 31], the group of patients with HPVposVSCC displayed a better OS and RFP than those with HPVnegVSCC (Additional file 3).
Furthermore, the recurrence rate increased from HPVposVSCC (13\%), HPVnegVSCC/p53wt (40\%) to $59 \%$ in HPVnegVSCC/p53abn (Additional file 2). Together this confirms our selection of a representative cohort of patients for our study.

\section{The HPVposVSCCs are most often strongly infiltrated with T cells}

The archived tissues sections were simultaneously analyzed for the expression of CD3, CD8, Foxp3, PD-1, and pan-keratin by multispectral immunofluorescence VECTRA analysis, both in the epithelial and stromal compartments (Additional file 4). Quantification of the T cells per square mm of tumor revealed that the stroma of VSCC was more densely infiltrated with $\mathrm{CD}^{+} \mathrm{T}$ cells, $\mathrm{CD}^{+} \mathrm{CD}^{-} \mathrm{Foxp}^{-} \mathrm{T}$ cells, $\mathrm{CD}^{+} \mathrm{CD}^{-}$Foxp $^{+}$Tregs, and $\mathrm{CD}^{+} \mathrm{CD}^{+}{ }^{+} \mathrm{Foxp}^{-} \mathrm{T}$ cells than healthy controls. The number of intraepithelial Tregs was also higher in VSCC (Fig. 1; Additional file 4; Additional file 5). Comparison of the three subgroups revealed a strong difference in $\mathrm{T}$ cell infiltration between HPVposVSCC and HPVnegVSCC/p53abn. The majority of HPVposVSCC was well infiltrated whereas the HPVnegVSCC/p53abn most often displayed a low Tcell infiltration. The group of HPVnegVSCC/p53wt showed a more variable pattern, with low and high T-cell infiltrated tumors (Fig. 1; Additional file 4; Additional file 5). The number of tumor-infiltrating intraepithelial cells was highly correlated to the other intraepithelial $\mathrm{T}$-cell subsets and to their numbers in the stroma (Additional file 6). This suggests a coordinated response of $\mathrm{CD}^{+} \mathrm{CD}^{-} \mathrm{Foxp}^{-}$and $\mathrm{CD}^{+} \mathrm{CD}^{+} \mathrm{Foxp}^{-} \mathrm{T}$ cells in VSCC. Quantification of intraepithelial $\mathrm{CD}^{+} \mathrm{Tbet}^{+} \mathrm{T}$ cells, representing type 1 immunity [27], revealed higher numbers in HPVposVSCC compared to both HPVnegVSCC subtypes (Fig. 1; Additional file 5).

\section{Immune inflamed, altered-excluded, altered- immunosuppressed and deserted VSCC}

Based on the previously published categories of T-cell infiltration patterns [32], the VSCC were characterized (Fig. 2) as immune-deserted $(n=19)$, -altered $(n=41)$ or -inflamed $(n=5)$. The immune-altered group was the largest and could be subdivided based on two distinct patterns of $\mathrm{T}$ cells in the stroma [33]. The altered-excluded tumors $(n=24)$ showed more stromal T cells at the invasive border whereas in the altered-immunosuppressed VSCC $(n=17) \mathrm{T}$ cells were dispersed throughout the whole stroma (Fig. 2). Notably, the number of $\mathrm{CD}^{+} \mathrm{T}$ cells at the invasive border (Fig. 2c) was highly correlated with the intraepithelial $\mathrm{CD}^{+} \mathrm{T}$-cell count $(p=0.000$; Additional file 6) in the altered-excluded VSCC. Moreover, the average number of intraepithelial $\mathrm{CD}^{+} \mathrm{T}$ cells in the altered-excluded was higher than in the altered-immune suppressed (mean $612 \pm$ SD 539 vs mean $157 \pm$ SD 92, $p<0.001$, respectively). To evaluate the impact of 


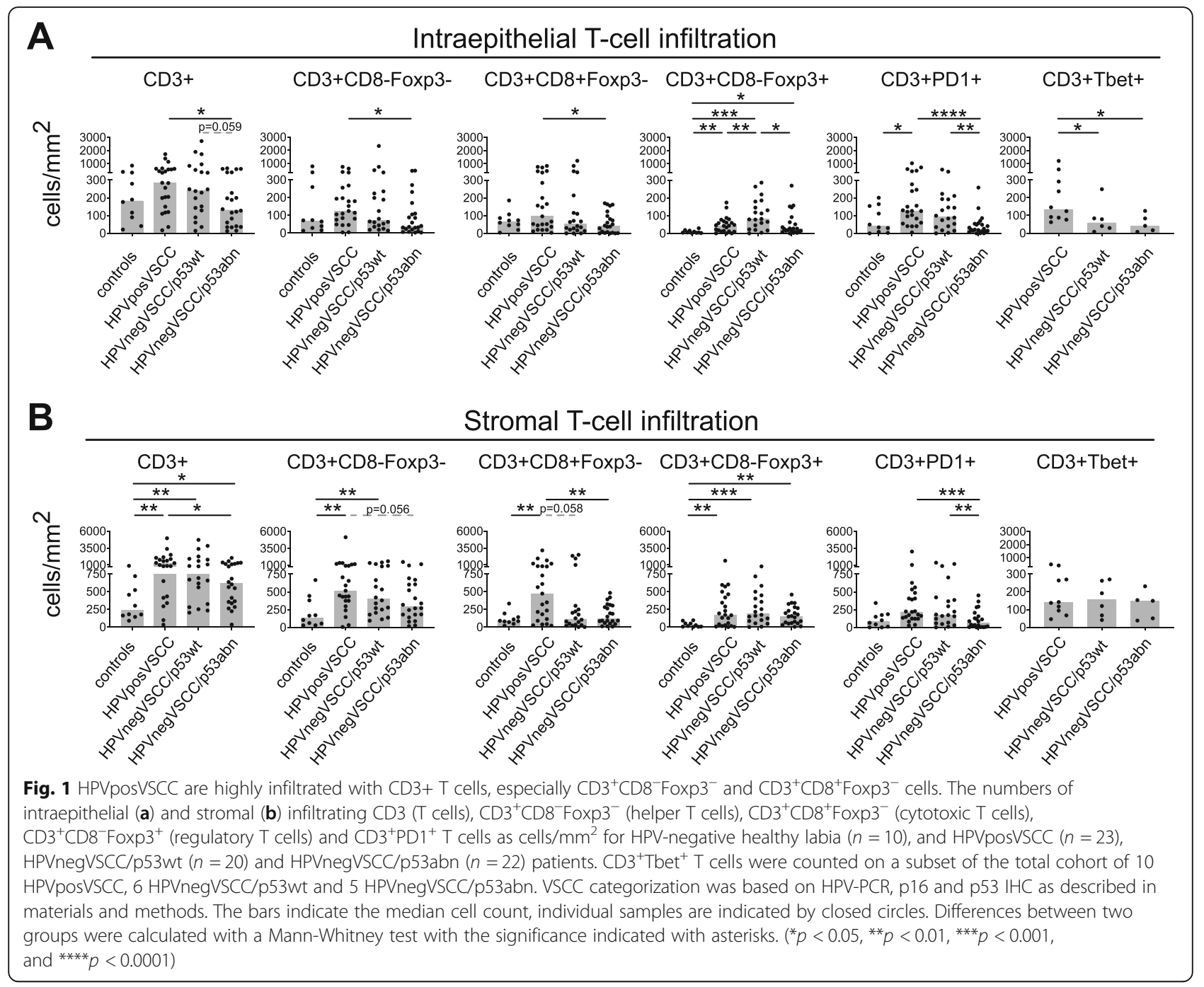

these four VSCC categories on survival, a Kaplan-Meier analysis was performed. The immune-inflamed group displayed a superior RFP and OS (Additional file 7). Interestingly, the group of altered-excluded VSCC showed a similar OS whereas the RFP was less good when compared to that of the immune-inflamed group. Therefore, the immune inflamed and altered-excluded VSCC were classified as hot tumors.

\section{The intratumoral $\mathrm{CD}^{+} \mathrm{CD}^{-} \mathrm{Foxp}^{-} \mathrm{T}$ cell count is an independent prognostic marker for RFP and OS irrespective of VSCC type}

The better OS of the two categories displaying stronger intraepithelial infiltration than altered-immune suppressed and immune-desert VSCC suggested an important role for intraepithelial $\mathrm{T}$ cells on clinical outcome. For each T-cell subset the median cell count (Additional file 8) and the optimized cut-off point, as determined by ROC curve analysis, was used to categorize the patients tumor into low or high infiltrated and subsequently its impact on clinical outcome was determined. High intraepithelial infiltration with $\mathrm{CD}^{+} \mathrm{T}$ cells, in particular of $\mathrm{CD}^{+} \mathrm{CD}^{-} \mathrm{Foxp}^{-} \mathrm{T}$ cells was strongly associated with longer RFP $(p=0.001)$ and OS $(p=0.004)$. A strong infiltration with $\mathrm{CD} 3^{+} \mathrm{PD} 1^{+} \mathrm{T}$ cells was also associated with a longer RFP $(p=0.032)$. The intraepithelial infiltration with $\mathrm{CD}^{+} \mathrm{CD}^{+} \mathrm{T}$ cells or $\mathrm{CD}^{+}{ }^{+} \mathrm{CD} 8^{-} \mathrm{Foxp}^{+}$Tregs was not prognostic for clinical outcome (Fig. 3; Additional file 9). Importantly, the prognostic power of $\mathrm{CD}^{+} \mathrm{CD}^{-} \mathrm{Foxp}^{-} \mathrm{T}$ cells for RFP was retained when only the HPVnegVSCC were analyzed (Additional file 9). To sustain this notion, the impact of tumor infiltrating $\mathrm{CD} 3^{+} \mathrm{CD} 8^{-} \mathrm{Foxp}^{-} \mathrm{T}$ cells in clinical outcome was corrected for age, and p53 and HPV status (Additional file 10). In the univariate analysis, only high $\mathrm{CD}^{+} \mathrm{CD}^{-}{ }^{-}$Foxp $3^{-}$counts and age correlated with RFP. In the multivariate analysis, high infiltration with $\mathrm{CD}^{+}{ }^{+} \mathrm{CD} 8^{-} \mathrm{Foxp}^{-} \mathrm{T}$ cells but not age was associated with longer RFP (HR 3.30 (1.22-8.94), 


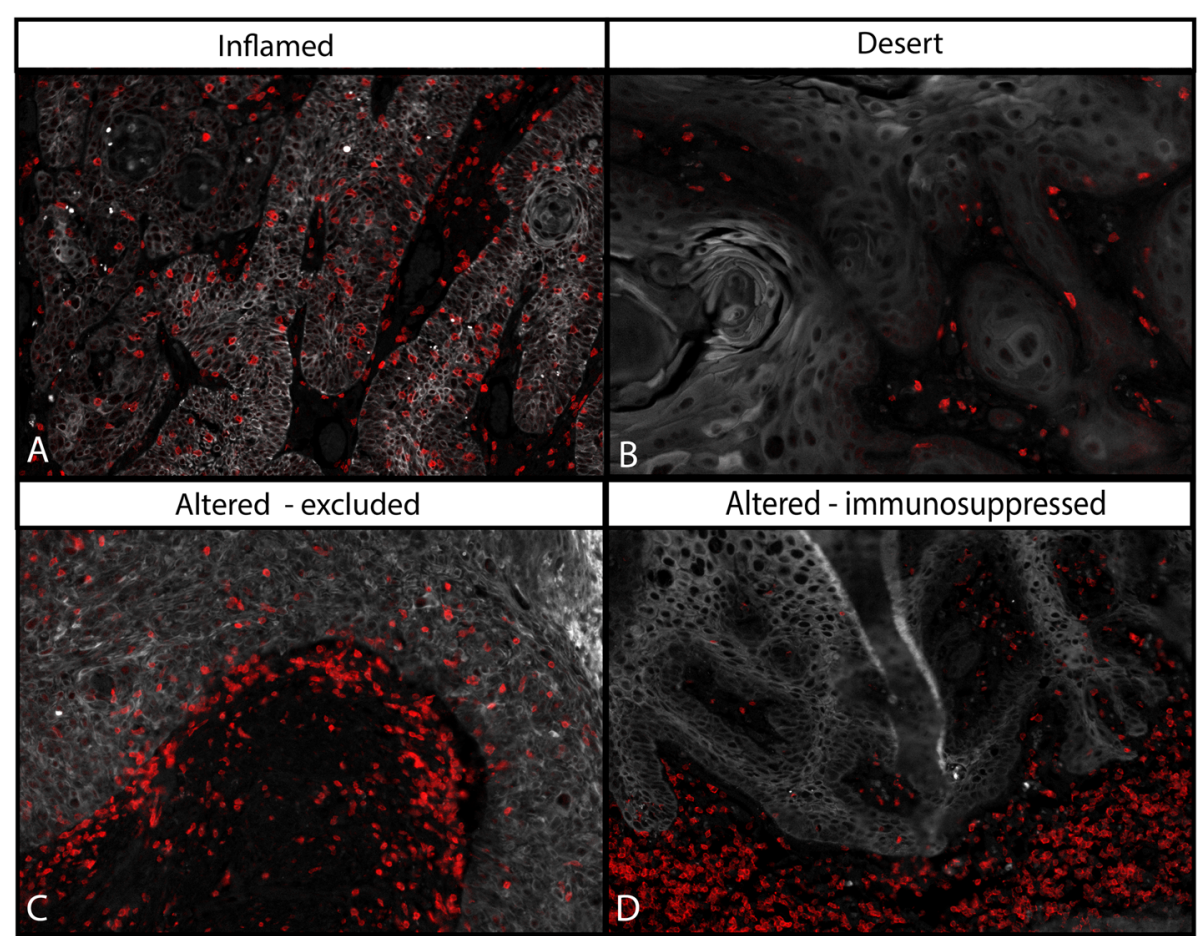

Fig. 2 The T-cell infiltration pattern can be used to classify VSCC into four categories. Categorization of the VSCC based on the pattern of T-cell infiltration was done according to literature [32, 33]. Depicted are four representative examples of T-cell infiltration patterns: designated immuneinflamed (a), - deserted (b), -altered excluded (c) and -altered immunosuppressed (d). Altered-excluded tumors show more T cells at the invasive border rather than in the middle of the stroma. $\operatorname{Red}=\mathrm{CD} 3$, white $=$ keratin (epithelial area)

$p=0.018)$. Thus, the $\mathrm{CD}^{+} \mathrm{CD} 8^{-} \mathrm{Foxp} 3^{-} \mathrm{T}$-cell infiltration is expected to be an important prognostic marker for clinical outcome, irrespective of whether these VSCC are caused by the HPV-derived oncogenes or other oncogenic pathways (e.g. p53 mutation).

\section{HPVnegVSCC are infiltrated by activated $\mathrm{CD} 8^{+}$and $\mathrm{CD} 4^{+}$ effector memory $\mathrm{T}$ cells}

The vast majority $(\sim 80 \%)$ of vulvar cancers are not induced by HPV. [17] While 78\% (18/23) of HPVposVSCC were strongly infiltrated with $\mathrm{CD}^{+} \mathrm{CD} 8^{-} \mathrm{Foxp}^{-} \mathrm{T}$ cells, there was also a considerable fraction of HPVnegVSCC displaying evidence of their immunogenicity with $60 \%$ $(12 / 20)$ of the HPVnegVSCC/p53wt and 40\% (9/22) of the HPVnegVSCC/p53abn showing high intraepithelial $\mathrm{CD}^{+} \mathrm{CD} 8^{-} \mathrm{Foxp}^{-} \mathrm{T}$-cell infiltration and longer RFP and OS. In order to gain a better understanding of these tumor-infiltrating T cells in HPVnegVSCC, a serie of fresh HPVnegVSCC tumor biopsies was used to culture tumorinfiltrating lymphocytes (TIL; $n=14$ ) and for ex-vivo phenotypic analysis of freshly dissociated and directly liquid nitrogen stored tumor-infiltrating $\mathrm{T}$ cells by flow cytometry $(n=12)$. Upon mitogenic stimulation, the growing TILs predominantly produced the type I cytokine IFN- $\gamma$ and the type 2 cytokine IL- 5 at on average similar concentrations, suggesting the presence of both Th1 and
Th2 cells in these tumors (Fig. 4). Only low concentrations of TNF- $\alpha$, IL- 4 and IL-10 were found.

To analyze the tumor-infiltrating $\mathrm{T}$ cells an antibody mix against CD45, CD3, CD4, CD8, CCR7, CD45RA, CD103, CD161, PD-1, CD38, HLA-DR and NKG2A was used to stain the fresh VSCC digests. In addition, PBMC of healthy female controls $(n=11)$ and PBMC of HPVnegVSCC $(n=29)$ were stained. A combined hierarchical Stochastical Neighbor Embedding (HSNE) analysis of the high-dimensional single cell data obtained from staining the blood and tumor samples resulted in the identification of several distinct immune populations (clusters), which were more prominently present or absent in the tumors or PBMC of the VSCC patients (Fig. 5a). In order to automatically discover stratifying biological signatures within VSCC blood and tumor samples, we made use of the automated and data-driven CITRUS platform, as an unbiased and thorough correlation-based tool for mining and inspection of cell subsets at the single cell level nested within high-dimensional datasets [34]. The CITRUS analysis resulted in ten distinctive (groups of) lymphocyte populations significantly higher present in one or more of the three different types of samples (Fig. 5b). The CD4 and CD8 distribution within the total $\mathrm{CD}^{+} \mathrm{T}$-cell population did not differ between PBMC and tumors of VSCC 


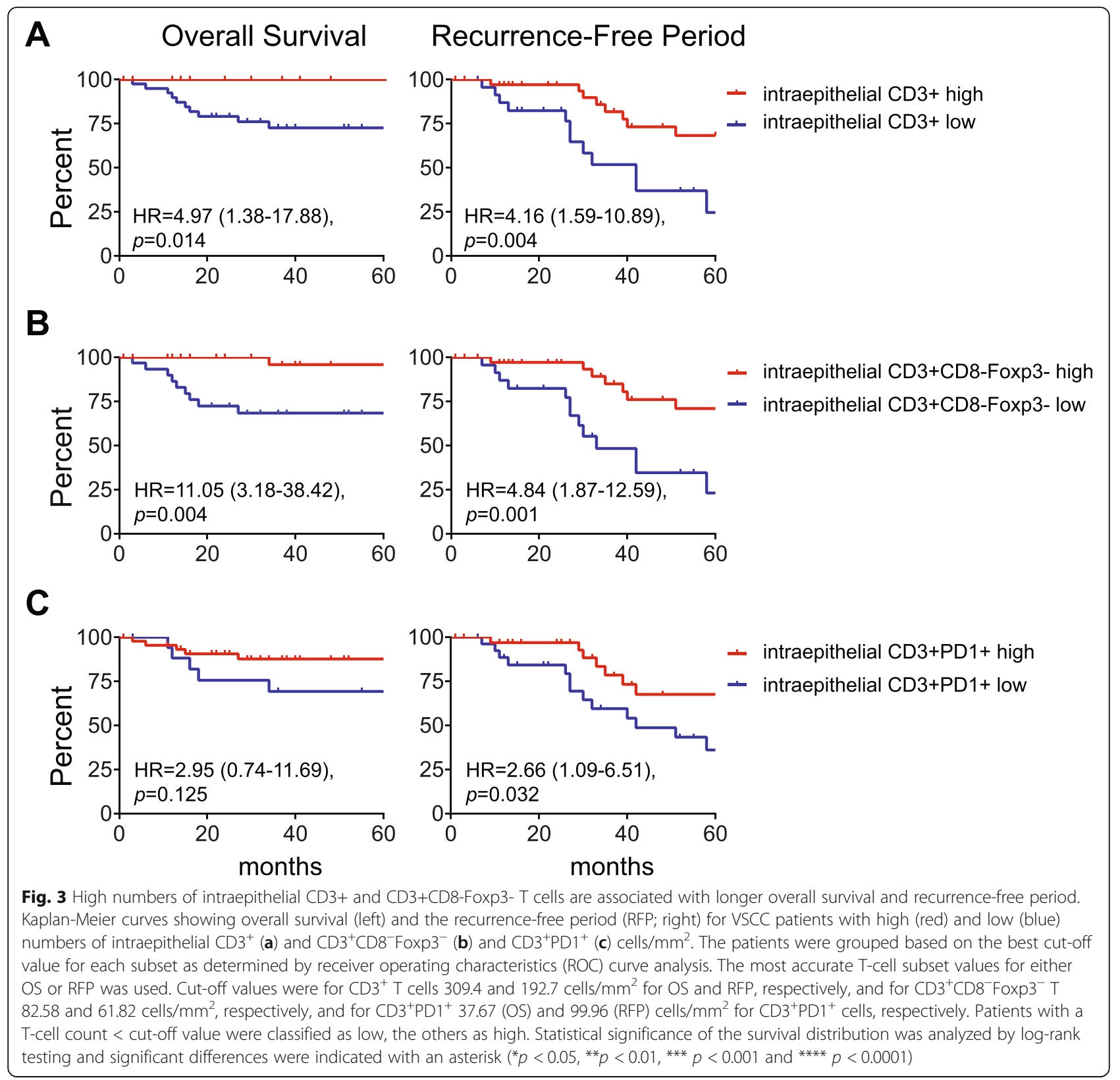

patients (Fig. 5c). Of the five identified $\mathrm{CD}^{+} \mathrm{T}$-cell subsets, populations 2, 4, and 5 were significantly underrepresented in VSCC tumors (Fig. 5d). Population 2 comprised $\mathrm{CD}^{+} \mathrm{CD} 161^{+} \mathrm{PD} 1^{+} \mathrm{CD} 38^{+} \mathrm{HLA}^{-} \mathrm{DR}^{-}$effector memory $\mathrm{RA}^{+} \mathrm{T}$ cells (Temra), whereas population 4 $\left(\mathrm{CD}^{+} \mathrm{Tcm} / \mathrm{em}\right)$ and population $5\left(\mathrm{CD}^{+}\right.$Temra $)$did not display these markers (Additional file 11). The $\mathrm{CD}^{+} \mathrm{T}$-cell population (\#1) which was clearly overrepresented in VSCC tumors, consisted of $\mathrm{CD}^{+} \mathrm{CD} 103^{+} \mathrm{CD} 161^{-} \mathrm{NKG}_{2} \mathrm{~A}^{+/-} \mathrm{PD} 1^{++} \mathrm{CD} 38^{++} \mathrm{HLA}^{-\mathrm{DR}^{+}}$ Tem cells. Of the five different $\mathrm{CD} 4^{+} \mathrm{T}$-cell subsets identified, population $6\left(\mathrm{CD} 4^{+} \mathrm{PD}-1^{-} \mathrm{CD} 161^{-} \mathrm{CD} 38^{++} \mathrm{HLA}^{-\mathrm{DR}}{ }^{-}\right.$ naïve $\mathrm{T}$ cells) and population $10 \quad\left(\mathrm{CD} 4^{+} \mathrm{PD}\right.$ $\left.1^{+} \mathrm{CD} 38^{-} \mathrm{CD} 161^{-} \mathrm{HLA}^{-D R^{-}} \mathrm{Tem} / \mathrm{cm}\right)$ were lower in VSCC than PBMC. In contrast, two populations of $\mathrm{CD}^{+}$effector $\mathrm{T}$ cells were found at significantly higher percentages and comprised CD $4^{+}$PD- $1^{++}$CD $161^{-}$CD $38^{+}{ }^{+}$LA-DR ${ }^{+}$Tem (\#7) as well as $\mathrm{CD}^{+} \mathrm{PD}-1^{-} \mathrm{CD} 161^{-} \mathrm{CD} 38^{-} \mathrm{HLA}^{-\mathrm{DR}}{ }^{-} \mathrm{Tcm} / \mathrm{em}$ (\#9). The co-expression of PD-1, CD38 and HLA-DR is indicative for T-cell activation. As such the strong tumor-specific infiltration of HPVnegVSCC with activated $\mathrm{CD} 8^{+}$ (population 1) and $\mathrm{CD}^{+}$(population 7) effector $\mathrm{T}$ cells sustains the notion these tumors are immunogenic and explain why their presence is associated with better clinical outcome.

For half (6/12) of the freshly digested VSCC samples enough material was available to characterize the $\mathrm{T}$ cell infiltrate with a second antibody mix against CD3, CD4, 


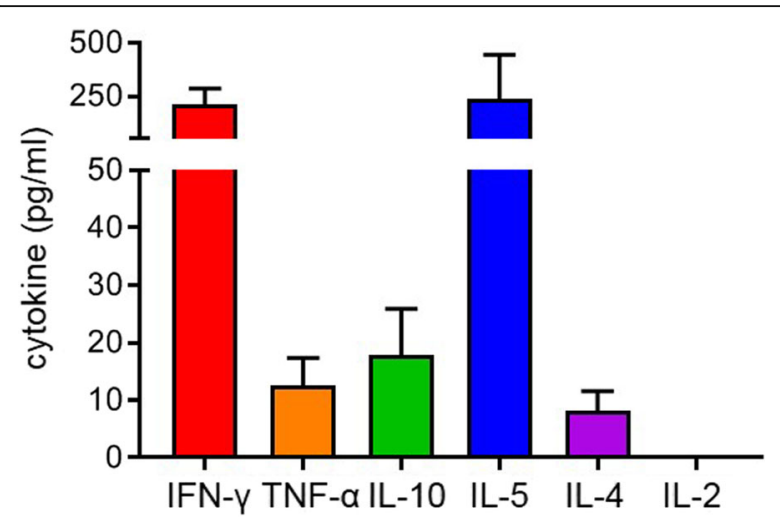

Fig. 4 Tumor-infiltrating lymphocytes produce Th1 and Th2 cytokines upon mitogenic stimulation. In vitro expanded T cells from VSCC were analyzed for their cytokine production following mitogenic stimulation with $0.5 \mu \mathrm{g} / \mathrm{ml}$ PHA for 4 days, after which supernatants were harvested and analyzed by cytometric bead array (CBA) to determine the production of IFN- $\gamma$, TNF- $a, I L-10, I L-5, I L-4$ and $\mathrm{IL}-2$ in $\mathrm{pg} / \mathrm{mL}$. Mean ( \pm SEM) cytokine production is shown for 14 HPVnegVSCC

CD8, CD25, CD127, Foxp3, Tim-3, Lag-3 and Tbet. These samples were analyzed for the presence of different types of Tregs, Tbet+ cells and the two checkpoint molecules according to the strategy shown in Additional file 12 . Similar to what was found in the FFPE tissue samples, a tumor-specific increase in activated and proliferating $\left(\mathrm{Ki}^{+} 7^{+}\right)$Tregs was observed (Fig. 6a). Furthermore, tumorspecific increases in the percentages of Tim-3 and Lag-3 Tregs, $\mathrm{CD}^{+}$and non-Treg $\mathrm{CD}^{+} \mathrm{T}$ cells were observed (Fig. 6b), confirming that part of the tumor-infiltrating $\mathrm{T}$ cells has been activated. Last but not least, on average 30\% of the $\mathrm{CD}^{+}$and $20 \%$ of the non-Treg $\mathrm{CD}^{+}{ }^{+} \mathrm{T}$ cells expressed the transcription factor Tbet, which is in line with the IFN- $\gamma$ production of the cultured TILs. Finally, only a small percentage of the Tregs expressed Tbet (Fig. 6b).

Based on the cytokine production and the expression of several checkpoints, transcription factors and activation markers, we conclude that HPVnegVSCC are infiltrated with variable numbers of activated type 1 and 2 $\mathrm{CD}^{+}$and $\mathrm{CD} 4^{+}$effector $\mathrm{T}$ cells as well as Tregs.

\section{Discussion}

We asked the question if the observed differences in recurrence rate and survival between the three subtypes of VSCC [14, 17], classified by the presence of HPV, the overexpression of p53 or the absence of both, may have an immunological background. Our study is the first to show that a strong infiltration of the tumor cell nests with helper $\left(\mathrm{CD}^{+} \mathrm{CD}^{-} \mathrm{Foxp}^{-}\right) \mathrm{T}$ cells is important for clinical outcome after primary surgery, irrespective of whether the VSCC are caused by HPV or other oncogenic pathways, including TP53 mutations. Probable reasons for the failure to detect this association in previous studies [6,9-11] are related to the importance of the location of the $\mathrm{T}$ cells in the tumor and the homogeneity in stage and treatment of the VSCC patients analyzed. In line with the RFP and the percentage of recurrences found in each of the three subtypes in VSCC, the percentage of tumors with high intraepithelial helper $\mathrm{T}$-cell infiltration was the highest in the HPV-driven VSCC (78\%), followed by VSCC not associated with HPV or p53 overexpression (60\%), and the lowest in VSCC with abnormal p53 expression (40\%). Importantly, these data suggest that T-cell infiltration of VSCC may be influenced by the oncogenic pathway underlying the development of a particular VSCC.

Although the helper $\mathrm{T}$ cells display the strongest relationship with clinical outcome, this does not mean that $\mathrm{CD}^{+} \mathrm{T}$ cells are not important in VSCC. Whenever there is a strong intraepithelial infiltration with $\mathrm{T}$ cells, this is because both subsets of $\mathrm{T}$ cells are present in large numbers. Furthermore, we noted a positive association between the intraepithelial presence of $\mathrm{CD} 3^{+} \mathrm{PD}-1^{+} \mathrm{T}$ cells and clinical outcome. In-depth flow cytometric analysis revealed that this $\mathrm{PD} 1^{+} \mathrm{T}$-cell population comprised activated $\mathrm{CD} 4^{+} \mathrm{PD}-1^{++} \mathrm{CD} 161^{-} \mathrm{CD} 38^{+} \mathrm{HLA}^{-} \mathrm{DR}^{+}$and $\mathrm{CD}^{+}{ }^{+} \mathrm{CD} 103^{+} \mathrm{CD}^{-} 161^{-} \mathrm{NKG}_{2} \mathrm{~A}^{+/} \mathrm{PD}^{++}{ }^{++} \mathrm{CD} 38^{++} \mathrm{HLA}^{-} \mathrm{DR}^{+}$ effector memory $\mathrm{T}$ cells. Potentially, helper $\mathrm{T}$ cells play an important role in VSCC because a substantial fraction of VSCC can partially downregulate HLA class I expression whilst the levels of tumor-expressed HLA class II may go up [35]. Based on the percentages of $\mathrm{T}$ cells co-expressing the transcription factor Tbet, as counted in the tumor sections and measured in fresh VSCC by flow cytometry, and by the detection of IFN- $\gamma$ and IL-5 in the supernatants of stimulated TIL, the VSCC-infiltrating T cells are both of a type 1 and 2 phenotype.

Current treatment of VSCC does not take into account the differences in etiology and clinical outcome [3]. The relationship between $\mathrm{T}$-cell infiltration and clinical outcome suggests that immunotherapy may form a new treatment option for VSCC, as in other tumor types this was associated with a better response to immunotherapy $[32,33]$. These other cancer types were categorized into immune-inflamed (hot), - altered (excluded or suppressed) and -deserted (cold) tumors in order to define which immunotherapeutic (combination) approach may work best. For instance, hot tumors show the best response to checkpoint blockade (e.g. anti-PD1 and antiCTLA-4) [32, 33]. Also VSCC could be divided according to these four immune phenotypes. Only a few (5 of 65) VSCC were categorized as truly immune-inflamed while a substantial portion $(37 \%, n=24)$ displayed the immune altered-excluded phenotype. However, the latter group displayed a significant stronger intraepithelial $\mathrm{T}$ cell infiltration when compared to the immune altered- 
A
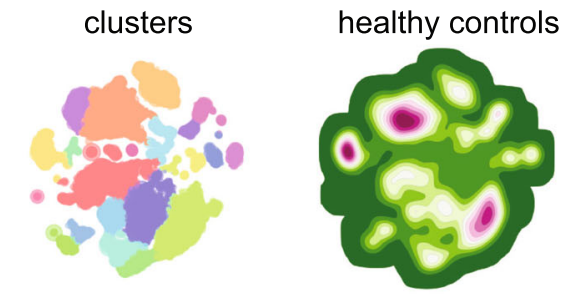

B

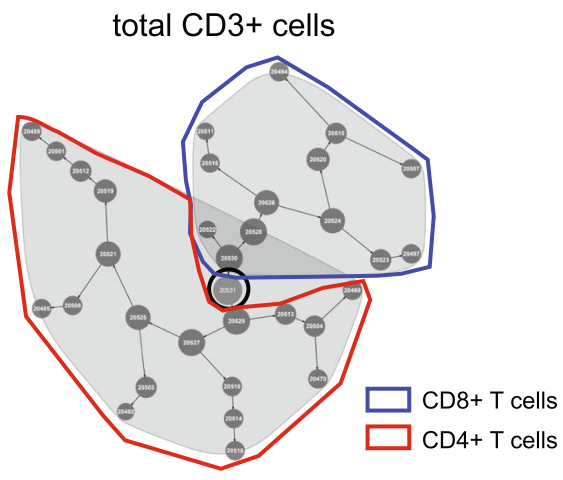

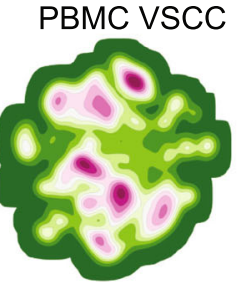

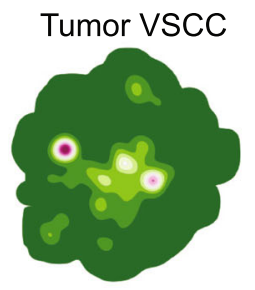

C

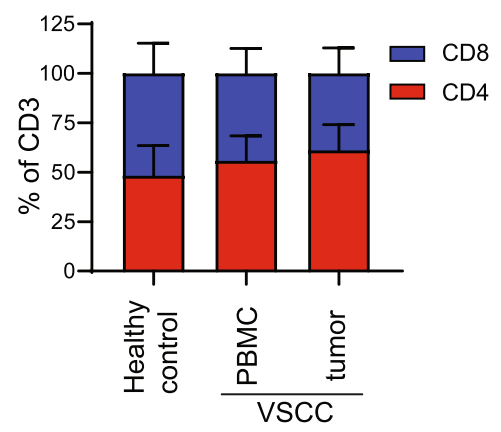

D

CD8+ T cell populations

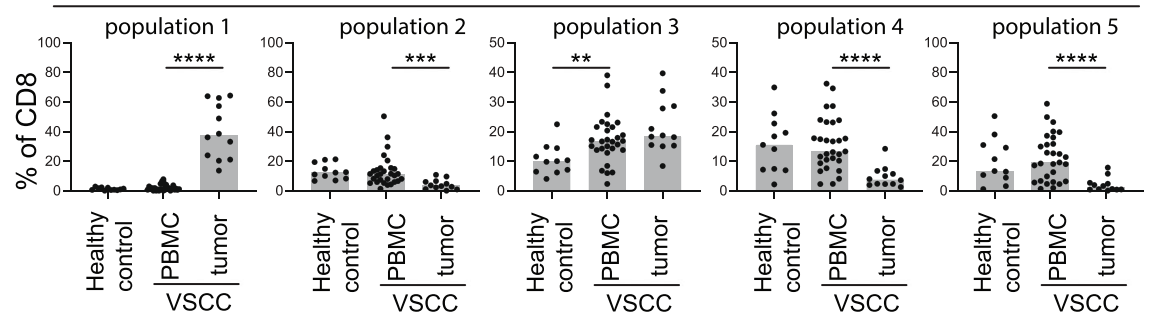

CD4+ T cell populations

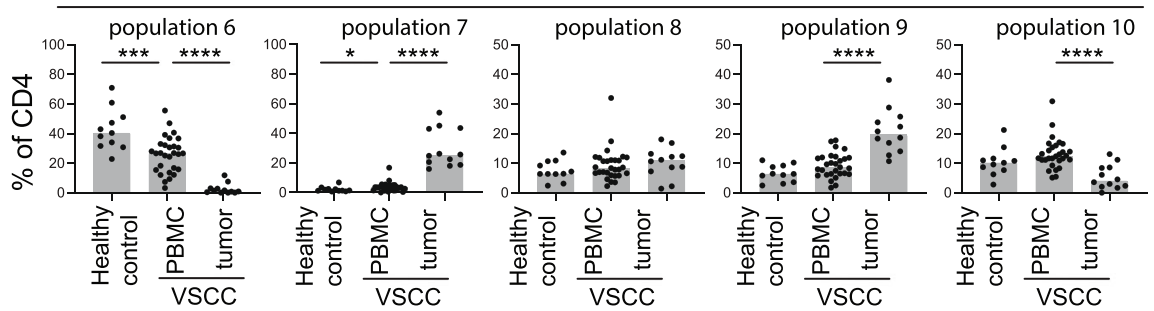

Fig. $5 \mathrm{HPVnegVSCC}$ are infiltrated with highly activated $\mathrm{CD} 4^{+}$and $\mathrm{CD} 8^{+}$effector/memory T cells. PBMC of healthy controls $(n=11)$ as well as PBMC $(n=29)$ and freshly dissociated tumor-derived TIL $(n=12)$ of HPVnegVSCC patients were analyzed by 13-parameter flow cytometry analysis. a Hierarchical Stochastical Neighbor Embedding (HSNE) clusters (left) and density plots (right) visualizing the high-dimensional flow cytometry data in two dimensions for the collective total $\mathrm{CD}^{+} \mathrm{T}$ cells for indicated groups. The identified cell subsets are identified in the cluster plots by the different colors. b CITRUS automatic discovery of stratifying biological signatures within tumor and blood samples visualizes 10 distinctive populations of $\mathrm{CD}^{+}$and $\mathrm{CD}^{+} \mathrm{T}$ cells the total $\mathrm{CD}^{+}$immune population. Every cell population represented by a node is divided on basis of median level of expression of a differently expressed marker into two new nodes (cellular subsets) going from the center (all cells) to the periphery of the plot. $\mathbf{c}$ The distribution of $\mathrm{CD}^{+}{ }^{+}$and $\mathrm{CD} 8^{+} \mathrm{T}$-cell frequencies (mean $\pm \mathrm{SEM}$ ) within the total $\mathrm{CD} 3^{+} \mathrm{T}$ cell population is depicted for healthy control and VSCC PBMC and tumors. $\mathbf{d}$ Scatter plots with bars displaying frequencies of CD8 $8^{+}$(\# 1 to 5; top panel) and CD4 $4^{+}$(\# 6 to 10; bottom panel) T cell populations are given as $\%$ of $C D 8^{+}$and $C D 4^{+}$cells. $\left({ }^{*} p<0.05,{ }^{* *} p<0.01,{ }^{* * *} p<0.001\right.$ and $\left.{ }^{* * *} p<0.0001\right)$

suppressed phenotype and showed a better OS. Patients with inflamed and immune altered-excluded VSCC may be selected for treatment with immunotherapy. In our study high percentages of intratumoral $\mathrm{T}$ cells expressed
PD-1. Others found variable percentages of cases in which the VSCC $(>30 \%)$ or VSCC-infiltrating immune cells $(>90 \%$ ) expressed PD-L1 [11, 36, 37], congruent with our observation that there are varying numbers of 


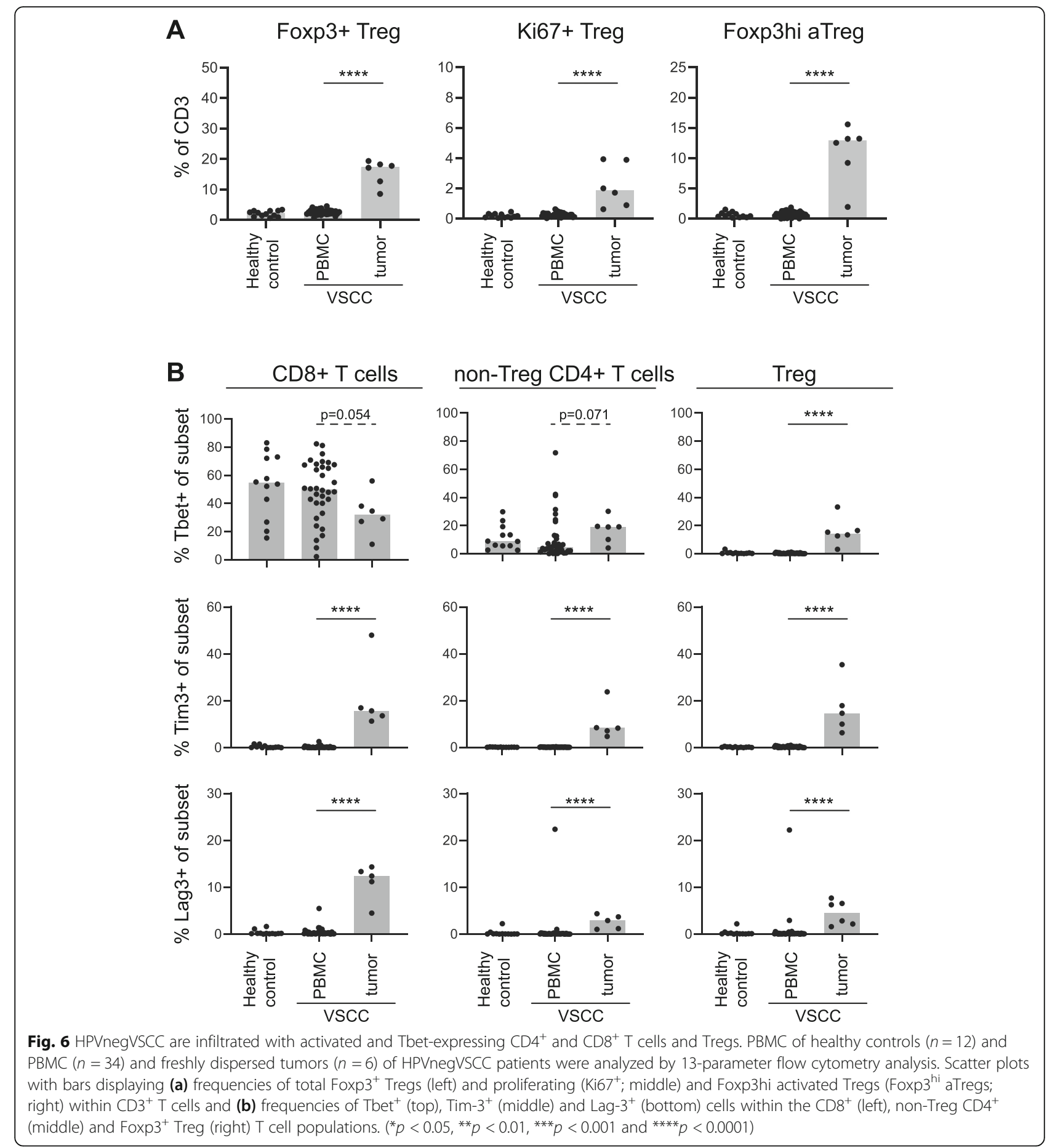

tumor-infiltrating $\mathrm{T}$ cells which can produce IFN- $\gamma$, as indicated by expression of Tbet, and may lead to adaptive PD-L1 expression [38]. Altogether, this makes a strong case for the treatment of inflamed and immune alteredexcluded VSCC with PD-1/PD-L1 checkpoint therapy. Indeed, a first successfully treated case with advanced stage recurrent vulvar cancer has been reported with PD-L1 blockade [39]. A tumor-specific increase of the CD4+ T- cell response seems more likely to be achieved by CTLA4blockade than by targeting PD-1 [40], arguing for a combination of PD-L1 and CTLA-4 blockade to reinvigorate the tumor-specific CD4+ T-cell response. Another option would be the use of an agonistic antibody to OX-40 [41], which in combination with PD-L1 blockade displayed synergistic effects on CD4+ T-cell reactivity [40]. Moreover, treatment of the generally T-cell infiltrated HPVposVSCC 
may include therapeutic HPV16 vaccination as HPVdriven oropharyngeal cancers responded well to the combination of checkpoint therapy and therapeutic vaccination [42].

One-third of our VSCC were phenotyped as immunedeserted or cold tumors which may exist because of a lack of antigens or their presentation (immune ignorance), or because of several deficits leading to a lack of priming or to tolerance [32, 42]. Apart from the HPV-induced VSCC, the viral proteins of which may drive a strong $\mathrm{T}$-cell response similar to what is seen in HPV-driven oropharyngeal cancer [24], 40-60\% of the HPVnegVSCC display strong intraepithelial $\mathrm{T}$ cell infiltration. This suggests that also in these tumors immunogenic tumor antigens are expressed and presented. Currently, the antigens recognized by $\mathrm{T}$ cells in HPVnegVSCC are unknown but the majority of primary VSCC express for instance the wellknown tumor antigens MAGEA1 and MAGEA4 [43], but it is unknown if these antigens function as target for the VSCC-infiltrating T-cells as this still needs to be studied. We have no data on a direct relation between the level of T-cell infiltration and the availability of strong tumor antigens expressed by VSCC, but our work on HPV-specific immunity in different cancers [25], as well as that of others in for instance melanoma [44-46], suggest that this is not the case. More likely, a lack of inflammation or danger signals has played a role in HPVnegVSCC. Intratumoral activation of the Stimulator of Interferon Genes (STING) pathway [44], the use of oncolytic viruses [45], but also intratumoral injections of toll-like receptor (TLR)-agonists [46] have been shown to sensitize cold tumors to checkpoint blockade. For cold VSCC tumors, the TLR7/8-agonist imiquimod may be a promising topically applied therapeutic agent. Imiquimod elevates numerous genes involved in the regulation of innate immunity, resulting in the migration of DC to the application site, and subsequently the activation of a type $1 \mathrm{~T}$-cell response [47]. Patients with a precancerous lesion of HPVposVSCC responded very well to imiquimod therapy [48]. Notably, imiquimod treatment of breast metastases in the skin not only converted them from cold to hot, as demonstrated by a profound infiltration with CD4+ and CD8+ T cells, but also led to tumor regression [49].

There are several limitations to our study. The correlation between better clinical outcome and intraepithelial T-cell infiltration was found in a highly homogeneous patient group with early stage cancer and treated with surgery. If this relationship also exists in locally advanced cancer patients treated with (chemo) radiotherapy has to be determined. Furthermore, next to the median cell count, we optimized the chance to detect a statistically significant relation between $\mathrm{T}$-cell subsets and clinical outcome in a relatively small group of patients. Hence our results need to be validated in a larger cohort. In addition, our data suggests that the etiology of the VSCC may have an impact on its immunogenicity. While this would fit with the concept that different oncogenic pathways may influence local immunity [18, 19], the numbers of VSCC analyzed are such that the outcome can only be used for hypothesis generation. Moreover, we have not analyzed the myeloid cell component, which on itself may impact prognosis and T-cell function. Finally, less than 20\% of VSCC are induced by HPV. As such, we merely collected small pieces of fresh tumor tissue and PBMCs from HPVnegVSCC patients. A more extensive comparison of the tumor-infiltrating immune phenotypes between HPV-induced and HPVnegVSCC, therefore, was not possible.

In conclusion, our observation that a strong coordinated intraepithelial infiltration with $\mathrm{T}$ cells is highly associated with a better clinical course of early stage VSCC after surgery and suggests that this group of patients may benefit from immunotherapy as an alternative to potential mutilating surgery in this delicate anatomical area [3]. In parallel to the use of the different categories of immune cell infiltrated tumors in other types of cancer [32,33], these tumor classifications can also be used to tailor immunotherapy approaches in VSCC. Near future studies should focus on the effects of checkpoint blockade in patients classified with inflamed and altered-excluded tumors while patients diagnosed with an immune-deserted (cold) VSCC may benefit more from therapies that induce acute inflammation. Furthermore, future studies should assess the mutational landscape of VSCC as this will reveal if a tumor-specific (neo)-antigen T-cell repertoire could be harnessed to treat the HPVnegVSCC as well as assess if the HPV-specific T-cell repertoire can be exploited to treat HPVposVSCC.

\section{Additional files}

Additional file 1: Antibody panels. (DOCX $19 \mathrm{~kb}$ )

Additional file 2: Patient characteristics of FFPE cohort. (DOCX $23 \mathrm{~kb}$ ) Additional file 3: HPVposVSCChave better overall survival compared to HPVnegVSCC. (PDF 260 kb)

Additional file 4: Tissue segmentation and image analysis by VECTRA and total T cell infiltrate in VSCC subtypes and healthy controls. (PDF 419 kb)

Additional file 5: Statistical differences in T-cell infiltration between VSCC subtypes and healthy controls. (DOCX $16 \mathrm{~kb}$ )

Additional file 6: Pearson correlations between the numbers of intraepithelial and stromal T cells. (DOCX 14 kb)

Additional file 7: Differences in survival for the four immune categories of VSCC. (PDF $300 \mathrm{~kb}$ )

Additional file 8: Median and optimized cut-off point by ROC curve analysis per phenotype and outcome. (DOCX 17 kb)

Additional file 9: Clinical impact of several subsets of intraepithelial T cells in the total group of VSCC and in HPVnegVSCCpatients only. (PDF $399 \mathrm{~kb}$ )

Additional file 10: Uni- and multivariate analysis for recurrence-free period. (DOCX $18 \mathrm{~kb}$ ) 
Additional file 11: Clustering analysis using CITRUS revealed 10 distinctive populations of CD4+ and CD8+ T cells. (PDF 643 kb)

Additional file 12: Gating strategy for CD8+, non-Treg CD4+ and regulatory (Treg) T-cell populations. (PDF $263 \mathrm{~kb}$ )

\section{Abbreviations}

Anti-CTLA-4: Anti-cytotoxic T-lymphocyte-associated protein 4; AntiPD1: Anti-programmed cell death protein 1; BSA: Bovine serum albumin; CTLA-4: Cytotoxic T-lymphocyte-associated protein 4; FCS: Fetal calf serum; FFPE: Formalin-fixed paraffin embedded; HLA: Human leukocyte antigen; HPV: Human papilloma virus; HPVnegVSCC: Human papilloma virus negative vulvar squamous cell carcinoma; HPVnegVSCC/p53abn: Human papilloma virus negative vulvar squamous cell carcinoma with p53 abnormal expression; HPVnegVSCC/p53wt: Human papilloma virus negative vulvar squamous cell carcinoma with p53 wildtype expression;

HPVposVSCC: Human papilloma virus positive vulvar squamous cell carcinoma; IDO: Indoleamine 2,3-dioxygenase; IFNY: Interferon-gamma; IL10: Interleukin-10; IL-4: Interleukin-4; IL-5: Interleukin-5; MAGEA1: Melanomaassociated antigen 1; MAGEA4: Melanoma-associated antigen 4; OS: Overall survival; p53wt: p53 wildtype; p53abn: p53 abnormal; PBMC: Peripheral blood mononuclear cells; PBS: Phosphate buffered saline; PD-1: Programmed cell death protein 1; PD-L1: Programmed cell death ligand 1;

PHA: Phytohemagglutinin; RFP: Recurrence-free period; ROC: Receiver operating characteristics; STING: Stimulator of interferon genes; Tcm: Central memory T cell; Tem: Effector memory T cell; Temra: Effector memory RA+ T cells; Th1: T-helper 1; Th2: T-helper 2; TIL: Tumor infiltrating lymphocyte; TNFa: Tumor necrosis factor alpha; Treg: Regulatory T cell; VSCC: Vulvar squamous cell carcinoma

\section{Acknowledgements}

We gratefully thank all the patients and healthy individuals who participated in this study. Furthermore Sandra van den Broek-Veldstra and Margriet Löwik for including the patients in the Circle study.

\section{Authors' contribution}

Conception and design: MvP, TB, SHvdB. Development of methodology: KK, SS, ZA, JvH, MvdT, IE. Acquisition of data: KK, SS, JvH, MvdT, IE. Analysis and interpretation of data: KK, SS, MvdT, TB, MvP, HvD, SHvdB. Writing, review, and/or revision of the manuscript: KK, SS, MvP, SHvdB. Patient management: HvD, MvP. Study supervision: TB, MvP, SHvdB. All authors read and approved the final manuscript.

\section{Funding}

This study was financially supported by grants from the Dutch Cancer Society 2016-10168 to MIEvP, TB, and SHvdB.

\section{Availability of data and materials}

All data generated or analyzed during this study are included in this published article (and its additional files) and are available from the corresponding author on reasonable request.

\section{Ethics approval and consent to participate}

The study was conducted in accordance with the Declaration of Helsinki and approved by the local medical ethical committee of the Leiden University Medical Center (P08.197 and B16.024) and in agreement with the Dutch law. The materials were used according to the Dutch Federation of Medical Research Association guidelines.

\section{Consent for publication}

Not applicable

\section{Competing interests}

The authors declare that they have no competing interests.

\section{Author details}

'Department of Gynecology, Oncode Institute, Leiden University Medical Centre, PO Box 9600, 2300 RC Leiden, The Netherlands. 'Department of Gynecology, Leiden University Medical Centre, PO Box 9600, 2300 RC Leiden, The Netherlands. ${ }^{3}$ Department of Medical Oncology, Oncode Institute, Leiden University Medical Centre, PO Box 9600, 2300 RC Leiden, The
Netherlands. ${ }^{4}$ Department of Gynecologic Oncology, Erasmus MC Cancer Institute, University Medical Center Rotterdam, PO Box 2040, 23000 CA Rotterdam, The Netherlands. ${ }^{5}$ Department of Pathology, Leiden University Medical Centre, PO Box 9600, 2300 RC Leiden, the Netherlands.

Received: 28 May 2019 Accepted: 16 August 2019

Published online: 03 September 2019

\section{References}

1. Mellman I, Hubbard-Lucey VM, Tontonoz MJ, Kalos MD, Chen DS, Allison JP, et al. De-risking immunotherapy: report of a consensus workshop of the Cancer immunotherapy consortium of the Cancer Research Institute. Cancer Immunol Res. 2016;4(4):279-88. https://doi.org/10.1158/2326-6066.Cir-16-0045.

2. van der Velden J, Fons G, Lawrie TA. Primary groin irradiation versus primary groin surgery for early vulvar cancer. Cochrane Database Syst Rev. 2011;(5): Cd002224. https://doi.org/10.1002/14651858.CD002224.pub2.

3. Gaarenstroom K, Kenter G, Trimbos J, Agous I, Amant F, Peters AA, et al. Postoperative complications after vulvectomy and inguinofemoral lymphadenectomy using separate groin incisions. Int J Gynecol Cancer. 2003;13(4):522-7.

4. Te Grootenhuis NC, Pouwer AW, de Bock GH, Hollema H, Bulten J, van der Zee AGJ, et al. Prognostic factors for local recurrence of squamous cell carcinoma of the vulva: A systematic review. Gynecol Oncol. 2017;148(3): 622-31. https://doi.org/10.1016/j.ygyno.2017.11.006.

5. Raspollini MR, Asirelli G, Taddei GL. Analysis of lymphocytic infiltrate does not help in prediction of vulvar squamous cell carcinoma arising in a background of lichen sclerosus. Int J Gynaecol Obstet. 2008;100(2):190-1. https://doi.org/10.1016/j.ijgo.2007.07.019.

6. Sznurkowski JJ, Zawrocki A, Emerich J, Biernat W. Prognostic significance of CD4+ and CD8+ T cell infiltration within cancer cell nests in vulvar squamous cell carcinoma. Int J Gynecol Cancer. 2011;21(4):717-21. https:// doi.org/10.1097/IGC.0b013e3182131f36.

7. van Esch EM, van Poelgeest MI, Kouwenberg S, Osse EM, Trimbos JB, Fleuren GJ, et al. Expression of coinhibitory receptors on $T$ cells in the microenvironment of usual vulvar intraepithelial neoplasia is related to proinflammatory effector $T$ cells and an increased recurrence-free survival. Int J Cancer. 2015;136(4):E95-106. https://doi.org/10.1002/ijc.29174.

8. van Esch EM, van Poelgeest MI, Trimbos JB, Fleuren GJ, Jordanova ES, van der Burg SH. Intraepithelial macrophage infiltration is related to a high number of regulatory $T$ cells and promotes a progressive course of HPV-induced vulvar neoplasia. Int J Cancer. 2015;136(4):E85-94. https://doi.org/10.1002/ijc.29173.

9. de Jong RA, Toppen NL, Ten Hoor KA, Boezen HM, Kema IP, Hollema H, et al. Status of cellular immunity lacks prognostic significance in vulvar squamous carcinoma. Gynecol Oncol. 2012;125(1):186-93. https://doi.org/1 $0.1016 / j . y g y n o .2011 .12 .416$

10. Sznurkowski JJ, Zawrocki A, Emerich J, Sznurkowska K, Biernat W. Expression of indoleamine 2,3-dioxygenase predicts shorter survival in patients with vulvar squamous cell carcinoma (VSCC) not influencing on the recruitment of FOXP3-expressing regulatory T cells in cancer nests. Gynecol Oncol. 2011; 122(2):307-12. https://doi.org/10.1016/j.ygyno.2011.04.050.

11. Hecking $T$, Thiesler T, Schiller C, Lunkenheimer JM, Ayub TH, Rohr A, et al. Tumoral PD-L1 expression defines a subgroup of poor-prognosis vulvar carcinomas with non-viral etiology. Oncotarget. 2017;8(54):92890-903. https://doi.org/10.18632/oncotarget.21641.

12. Taube JM, Anders RA, Young GD, Xu H, Sharma R, McMiller TL, et al. Colocalization of inflammatory response with B7-h1 expression in human melanocytic lesions supports an adaptive resistance mechanism of immune escape. Sci Transl Med. 2012;4(127):127ra37. https://doi.org/10.1126/ scitranslmed.3003689.

13. Sznurkowski JJ, Zawrocki A, Biernat W. Subtypes of cytotoxic lymphocytes and natural killer cells infiltrating cancer nests correlate with prognosis in patients with vulvar squamous cell carcinoma. Cancer Immunol Immunother. 2014;63(3):297-303. https://doi.org/10.1007/s00262-013-1511-x.

14. Nooij LS, Ter Haar NT, Ruano D, Rakislova N, van Wezel T, Smit V, et al. Genomic characterization of vulvar (pre) cancers identifies distinct molecular subtypes with prognostic significance. Clin Cancer Res. 2017;23(22):6781-9. https://doi.org/10.1158/1078-0432.ccr-17-1302.

15. van de Nieuwenhof HP, van Kempen LC, de Hullu JA, Bekkers RL, Bulten J, Melchers WJ, et al. The etiologic role of HPV in vulvar squamous cell 
carcinoma fine tuned. Cancer Epidemiol Biomark Prev. 2009;18(7):2061-7. https://doi.org/10.1158/1055-9965.epi-09-0209.

16. Dong F, Kojiro S, Borger DR, Growdon WB, Oliva E. Squamous cell carcinoma of the vulva: a subclassification of 97 cases by Clinicopathologic, Immunohistochemical, and molecular features (p16, p53, and EGFR). Am J Surg Pathol. 2015;39(8):1045-53. https://doi.org/10.1097/pas. 0000000000000454.

17. Hinten F, Molijn A, Eckhardt L, Massuger L, Quint W, Bult P, et al. Vulvar cancer: two pathways with different localization and prognosis. Gynecol Oncol. 2018;149(2):310-7. https://doi.org/10.1016/j.ygyno.2018. 03.003 .

18. Spranger S, Bao R, Gajewski TF. Melanoma-intrinsic beta-catenin signalling prevents anti-tumour immunity. Nature. 2015;523(7559):231-5. https://doi. org/10.1038/nature14404.

19. Peng W, McKenzie JA, Hwu P. Complementing T-cell function: an inhibitory role of the complement system in T-cell-mediated antitumor immunity. Cancer Discov. 2016;6(9):953-5. https://doi.org/10.1158/21598290.Cd-16-0698.

20. de Sanjose S, Alemany L, Ordi J, Tous S, Alejo M, Bigby SM, et al. Worldwide human papillomavirus genotype attribution in over 2000 cases of intraepithelial and invasive lesions of the vulva. Eur J Cancer. 2013:49(16): 3450-61. https://doi.org/10.1016/j.ejca.2013.06.033.

21. Piersma SJ, Welters MJ, van der Hulst JM, Kloth JN, Kwappenberg KM, Trimbos BJ, et al. Human papilloma virus specific T cells infiltrating cervical cancer and draining lymph nodes show remarkably frequent use of HLADQ and -DP as a restriction element. Int J Cancer. 2008;122(3):486-94. https://doi.org/10.1002/ijc.23162.

22. de Vos van Steenwijk PJ, Heusinkveld M, Ramwadhdoebe TH, Lowik MJ, van der Hulst JM, Goedemans R, et al. An unexpectedly large polyclonal repertoire of HPV-specific T cells is poised for action in patients with cervical cancer. Cancer Res. 2010;70(7):2707-17. https://doi. org/10.1158/0008-5472.can-09-4299.

23. Ijsselsteijn ME, Brouwer TP, Abdulrahman Z, Reidy E, Ramalheiro A, Heeren AM, et al. Cancer immunophenotyping by 7 colour multispectral imaging without tyramide signal amplification. J Pathol Clin Res. 2018;5(1):3-11. https://doi.org/10.1002/cjp2.113.

24. Welters MJP, Ma W, Santegoets S, Goedemans R, Ehsan I, Jordanova ES, et al. Intratumoral HPV16-specific T cells constitute a type I-oriented tumor microenvironment to improve survival in HPV16-driven oropharyngeal Cancer. Clin Cancer Res. 2018;24(3):634-47. https://doi. org/10.1158/1078-0432.ccr-17-2140.

25. Santegoets SJ, van Ham VJ, Ehsan I, Charoentong P, Duurland CL, van Unen $V$, et al. The Anatomical Location Shapes the Immune Infiltrate in Tumors of Same Etiology and Affects Survival. Clin Cancer Res. 2018;25(1):240-52. https://doi.org/10.1158/1078-0432.Ccr-18-1749.

26. Santegoets SJ, Dijkgraaf EM, Battaglia A, Beckhove P, Britten CM, Gallimore $A$, et al. Monitoring regulatory T cells in clinical samples: consensus on an essential marker set and gating strategy for regulatory $T$ cell analysis by flow cytometry. Cancer Immunol Immunother. 2015;64(10):1271-86. https:// doi.org/10.1007/s00262-015-1729-X.

27. Santegoets SJ, Duurland CL, Jordanova ES, van Ham JJ, Ehsan I, van Egmond $\mathrm{SL}$, et al. Tbet-positive regulatory $T$ cells accumulate in oropharyngeal cancers with ongoing tumor-specific type $1 \mathrm{~T}$ cell responses. J Immunother Cancer. 2019;7(1):14. https://doi.org/10.1186/s40425-019-0497-0.

28. Pezzotti N, Höllt T, Lelieveldt B, Eisemann E, Vilanova A. Hierarchical Stochastic Neighbor Embedding. Compt Graph Forum. 2016;35:21-30.

29. Welters MJP, Ma W, Santegoets SJ, Goedemans R, Ehsan I, Jordanova ES, et al. Intratumoral HPV16-specific T-cells constitute a type 1 oriented tumor microenvironment to improve survival in HPV16-driven oropharyngeal cancer. Clin Cancer Res. 2017;24(3):634-47. https://doi.org/10.1158/10780432.ccr-17-2140.

30. Rumbold AR, Tan SE, Condon JR, Taylor-Thomson D, Nickels M, Tabrizi SN, et al. Investigating a cluster of vulvar cancer in young women: a crosssectional study of genital human papillomavirus prevalence. BMC Infect Dis. 2012;12:243. https://doi.org/10.1186/1471-2334-12-243.

31. Monk BJ, Burger RA, Lin F, Parham G, Vasilev SA, Wilczynski SP. Prognostic significance of human papillomavirus DNA in vulvar carcinoma. Obstet Gynecol. 1995;85(5 Pt 1):709-15.

32. Chen DS, Mellman I. Elements of cancer immunity and the cancerimmune set point. Nature. 2017;541(7637):321-30. https://doi.org/10.103 8/nature21349.
33. Galon J, Bruni D. Approaches to treat immune hot, altered and cold tumours with combination immunotherapies. Nat Rev Drug Discov. 2019; 18(3):197-218. https://doi.org/10.1038/s41573-018-0007-y.

34. Bruggner RV, Bodenmiller B, Dill DL, Tibshirani RJ, Nolan GP. Automated identification of stratifying signatures in cellular subpopulations. Proc Natl Acad Sci U S A. 2014;111(26):E2770-7. https://doi.org/10.1073/pnas.1408792111.

35. van Esch EM, Tummers B, Baartmans V, Osse EM, Ter Haar N, Trietsch MD, et al. Alterations in classical and nonclassical HLA expression in recurrent and progressive HPV-induced usual vulvar intraepithelial neoplasia and implications for immunotherapy. Int J Cancer. 2014;135(4):830-42. https:// doi.org/10.1002/ijc.28713.

36. Howitt BE, Sun HH, Roemer MG, Kelley A, Chapuy B, Aviki E, et al. Genetic basis for PD-L1 expression in squamous cell carcinomas of the cervix and vulva. JAMA Oncol. 2016;2(4):518-22. https://doi.org/10.1001/ jamaoncol.2015.6326.

37. Thangarajah F, Morgenstern B, Pahmeyer C, Schiffmann LM, Puppe J, Mallmann $\mathrm{P}$, et al. Clinical impact of PD-L1 and PD-1 expression in squamous cell cancer of the vulva. J Cancer Res Clin Oncol. 2019;145(6): 1651-60. https://doi.org/10.1007/s00432-019-02915-1.

38. Garcia-Diaz A, Shin DS, Moreno BH, Saco J, Escuin-Ordinas H, Rodriguez GA, et al. Interferon receptor signaling pathways regulating PD-L1 and PD-L2 expression. Cell Rep. 2017;19(6):1189-201. https://doi.org/10.1016/ j.celrep.2017.04.031.

39. Shields LBE, Gordinier ME. Pembrolizumab in Recurrent Squamous Cell Carcinoma of the Vulva: Case Report and Review of the Literature. Gynecol Obstet Investig. 2018:84:1-5. https://doi.org/10.1159/000491090.

40. Wei SC, Levine JH, Cogdill AP, Zhao Y, Anang NAS, Andrews MC, et al. Distinct Cellular Mechanisms Underlie Anti-CTLA-4 and Anti-PD-1 Checkpoint Blockade. Cell. 2017;170(6):1120-1133.e17. https://doi.org/10.1 016/j.cell.2017.07.024.

41. Hirschhorn-Cymerman D, Budhu S, Kitano S, Liu C, Zhao F, Zhong H, et al. Induction of tumoricidal function in CD4+ T cells is associated with concomitant memory and terminally differentiated phenotype. J Exp Med. 2012;209(11):2113-26. https://doi.org/10.1084/jem.20120532.

42. Massarelli E, William W, Johnson F, Kies M, Ferrarotto R, Guo M, et al. Combining immune checkpoint blockade and tumor-specific vaccine for patients with incurable human papillomavirus 16-related Cancer: a phase 2 clinical trial. JAMA Oncol. 2019;5(1):67-73. https://doi.org/10.1001/ jamaoncol.2018.4051.

43. Sznurkowski JJ, Zawrocki A, Karczewska J, Emerich J, Biernat W. Should we consider cancer/testis antigens NY-ESO-1, MAGE-A4 and MAGE-A1 as potential targets for immunotherapy in vulvar squamous cell carcinoma? Histopathology. 2011;58(3):481-3. https://doi.org/10.1111/ j.1365-2559.2011.03772.x.

44. Corrales L, McWhirter SM, Dubensky TW Jr, Gajewski TF. The host STING pathway at the interface of cancer and immunity. J Clin Invest. 2016;126(7): 2404-11. https://doi.org/10.1172/jci86892.

45. Bourgeois-Daigneault MC, Roy DG, Aitken AS, El Sayes N, Martin NT, Varette $\mathrm{O}$, et al. Neoadjuvant oncolytic virotherapy before surgery sensitizes triplenegative breast cancer to immune checkpoint therapy. Sci Transl Med. 2018;10(422):eaao1641. https://doi.org/10.1126/scitranslmed.aao1641.

46. Sato-Kaneko F, Yao S, Ahmadi A, Zhang SS, Hosoya T, Kaneda MM, et al. Combination immunotherapy with TLR agonists and checkpoint inhibitors suppresses head and neck cancer. JCI Insight. 2017;2(18):93397. https://doi. org/10.1172/jci.insight.93397.

47. Schon MP, Schon M. Imiquimod: mode of action. Br J Dermatol. 2007; 157(Suppl 2):8-13. https://doi.org/10.1111/j.1365-2133.2007.08265.x.

48. van Seters $M$, van Beurden M, ten Kate FJ, Beckmann I, Ewing PC, Eijkemans MJ, et al. Treatment of vulvar intraepithelial neoplasia with topical imiquimod. N Engl J Med. 2008;358(14):1465-73. https://doi. org/10.1056/NEJMoa072685.

49. Adams S, Kozhaya L, Martiniuk F, Meng TC, Chiriboga L, Liebes L, et al. Topical TLR7 agonist imiquimod can induce immune-mediated rejection of skin metastases in patients with breast cancer. Clin Cancer Res. 2012;18(24): 6748-57. https://doi.org/10.1158/1078-0432.ccr-12-1149.

\section{Publisher's Note}

Springer Nature remains neutral with regard to jurisdictional claims in published maps and institutional affiliations. 